\title{
Energy metabolism and rheumatic diseases: from cell to organism
}

\author{
Cornelia M Spies*1, Rainer H Straub² and Frank Buttgereit'
}

\begin{abstract}
In rheumatic and other chronic inflammatory diseases, high amounts of energy for the activated immune system have to be provided and allocated by energy metabolism. In recent time many new insights have been gained into the control of the immune response through metabolic signals. Activation of immune cells as well as reduced nutrient supply and hypoxia in inflamed tissues cause stimulation of glycolysis and other cellular metabolic pathways. However, persistent cellular metabolic signals can promote ongoing chronic inflammation and loss of immune tolerance. On the organism level, the neuroendocrine immune response of the hypothalamic-pituitary adrenal axis and sympathetic nervous system, which is meant to overcome a transient inflammatory episode, can lead to metabolic disease sequelae if chronically activated. We conclude that, on cellular and organism levels, a prolonged energy appeal reaction is an important factor of chronic inflammatory disease etiology.
\end{abstract}

\section{Introduction}

Energy metabolism is an important part of the background machinery that ensures proper function of immune cells and the immune system [1]. In rheumatic disease and other chronic inflammatory diseases (CIDs), the activation of the immune system consumes vast amounts of energy (that is, up to $2,000 \mathrm{~kJ} /$ day and more) [2]. In recent years many new insights have been gained into multilevel interactions between metabolic and immune systems [3-7]. An increasing body of evidence suggests that energy metabolism is crucial for the maintenance of chronic inflammation, not only in terms of energy supply but also in the control of the immune

*Correspondence: cornelia.spies@charite.de

'Department of Rheumatology and Clinical Immunology, Charité University Medicine Berlin, Charitéplatz 1, 10117 Berlin, Germany

Full list of author information is available at the end of the article response through metabolic signals [8-11]. The interplay between immunology and metabolism thus plays a central role in the pathophysiology of CIDs and bears great therapeutic potential. In this review we provide an update on recent findings in the field of energy metabolism in chronic inflammation and CIDs, firstly focusing on the cellular level and secondly considering the energy metabolism of the organism and consequences for CIDs.

\section{Energy metabolism in the cell Cellular energy metabolism}

The main donor of free energy in cells is ATP [1], which is generated both by glycolysis and by oxidative phosphorylation (OXPHOS) [12-14]. Most cells break down glucose to pyruvate via cytosolic glycolysis, and then oxidize pyruvate to carbon dioxide in the mitochondrial tricarboxylic acid cycle, generating most of the ATP through OXPHOS at the electron transport chain [1214]. Nutrients such as fatty acids and amino acids can also be degraded to pyruvate, acetyl-coenzyme A, or other intermediates of the tricarboxylic acid cycle to maintain ATP production [4]. In contrast, in many cancer cells and activated $\mathrm{T}$ cells, pyruvate is preferentially converted into lactate that is secreted from the cells, rather than pyruvate being oxidized in the mitochondria [12-14]. By this process - known as aerobic glycolysis (also called the Warburg effect) - only two ATP molecules per molecule of glucose are yielded, compared with a maximum of 36 ATP molecules when glycolysis is coupled to OXPHOS $[4,12,14]$. Although it seems counterintuitive for cells to use a low-efficiency pathway to produce ATP under conditions of high energy demand, it has been proposed that aerobic glycolysis produces the requisite reducing equivalents and biosynthetic substrates that are required for proliferation $[12,14]$.

\section{Cellular nutrient sensing pathways}

The serine/threonine kinases AKT1 to AKT3, AMP activated protein kinase (AMPK), mammalian target of rapamycin (mTOR), and LKB1 (also known as STK11) are regarded as cellular nutrient sensors that help to maintain energy homeostasis by relaying signals that 
determine how cells respond to high or low levels of intracellular carbohydrates or amino acids [5]. Activated $\mathrm{AKT}$, also known as protein kinase $\mathrm{B}$, is induced by phosphoinositide 3-kinase (PI3K) and represents the primary downstream mediator of the metabolic effects of insulin [15]. In T cells, AKT is activated by T-cell receptor/CD28 co-stimulation and growth factors/cytokines such as IL-2 or IL-7 [16,17] (Figure 1). AKT increases glucose uptake by stimulating the localization of glucose transporters to the plasma membrane, and it can increase glycolysis by promoting the activities of the rate-limiting glycolytic enzymes hexokinase and phosphofructokinase [18]. AKT activates mTOR, a key regulator of translation and major effector of cell growth and proliferation, which increases the expression of amino acid transporters $[19,20]$. mTOR forms two distinct complexes, mTORC1 and mTORC2, respectively. mTORC1 stimulates diverse metabolic pathways, including glycolysis, the oxidative arm of the pentose phosphate pathway, and de novo lipid biosynthesis [21].

Mammalian AMPK, another evolutionarily conserved protein kinase, which is a metabolic master switch and fuel gauge, is activated under conditions that increase the AMP/ATP ratio, including glucose deprivation and hypoxia [22]. Once activated, these kinases mediate the upregulation of energy-producing catabolic processes, such as fatty acid oxidation and glycolysis, and downregulate energy-consuming anabolic metabolism [22,23]. The phosphorylation of the mTORC1 component raptor by AMPK is required for the inhibition of $\mathrm{mTORC} 1$ and cell-cycle arrest induced by energy stress [24]. There is complex crosstalk between the highly conserved nutrient sensors and the molecular clock of peripheral cells coordinating the circadian control of energy supply on a cellular level $[25,26]$.

\section{Energy metabolism of immune cells}

Immune cells require energy for housekeeping functions as well as for specific immune functions (Table 1). The main housekeeping functions that use significant amounts of ATP are processes of ion transport and macromolecule synthesis. Specific immune functions include motor functions, antigen processing and presentation, activation and effector functions such as synthesis of antibodies, cytotoxicity, and regulatory functions [1] (Table 1). Calculations show that a quiescent leukocyte needs $1.1 \times 10^{-11} \mathrm{~mol} \mathrm{ATP} /$ day for protein production and $5.5 \times 10^{-11} \mathrm{~mol} \mathrm{ATP} /$ day in total [2]. Activation of quiescent leukocytes leads to an increase of energy expenditure by a factor of 1.3 to 1.5 [2], so an activated leukocyte needs $7.2 \times 10^{-11}$ to $8.3 \times 10^{-11} \mathrm{~mol} \mathrm{ATP} /$ day.

The cellular energy metabolism is relevant to be considered in terms of diseases, for example in cells within the inflamed rheumatoid arthritic joint, because energy supply is limited $[27,28]$. Firstly, due to the invasion of immune cells and tissue swelling, the relative oxygen/cell ratio is decreased. Secondly, cell accumulation and inflammatory edema increase the distance between cells and oxygen-supplying arterial vessels. Thirdly, vasodilatation, as induced by inflammatory mediators such as prostaglandin $\mathrm{E}_{2}$, lowers blood flow and thus the supply of oxygen and nutrients is reduced (such as glucose and amino acids) as well as the removal of metabolic waste (such as lactate and carbon dioxide) $[27,28]$.

\section{Immune cell function is maintained under restricted energy supply}

A recent investigation of the energy-adaptive potential of human stimulated $\mathrm{CD}_{4}{ }^{+} \mathrm{T}$-helper cells under conditions of impaired OXPHOS and/or low glucose (which inhibits glycolysis) demonstrated that OXPHOS and glycolysis are completely interchangeable in terms of ATP production [29]. Furthermore, specific T-cell functions such as cytokine production and proliferation are unaffected in glucose-containing medium, even under complete OXPHOS suppression. Only when glucose is also absent are these functions significantly decreased [29]. Human $\mathrm{CD}^{+} \mathrm{T}$ cells thus own a high adaptive potential to maintain specific functions even under severely impaired bioenergetic conditions. However, proliferation and cytokine production of human $\mathrm{CD}^{+} \mathrm{T}$ cells are despite a high adaptive potential - dependent on a certain supply with energy, and glucose is obviously of crucial importance for proliferation not only from the bioenergetic point of view as a substrate for ATP synthesis, but also in terms of being either directly and/or indirectly and essentially involved (for example, as a precursor molecule for macromolecule synthesis) in key steps of cellular proliferation and cytokine synthesis $[27,29]$.

\section{Hypoxia is present in the inflamed joint}

Another study on stimulated human $\mathrm{CD}^{+} \mathrm{T}$ cells examined the effect of limited oxygen availability and/or lack of glucose, and found both that cumulative hypoxia stimulates the secretion of proinflammatory and proangiogenic cytokines in the presence of glucose and that the lack of glucose resulted in lower cytokine concentrations [27]. These observations support the view of hypoxia being a key driving factor in chronic inflammation. The first data indicating the hypoxic nature of the rheumatoid arthritis (RA) synovium were achieved in the 1970s by measuring oxygen tension by means of a Clarktype electrode in samples of synovial fluids of patients with RA [28,30,31]. Hypoxia has been demonstrated in patients with RA undergoing surgery for tendon rupture by Sivakumar and colleagues [32]. Just recently, by means of a novel oxygen-sensing probe in vivo, even a direct relationship between tissue partial pressure of oxygen 


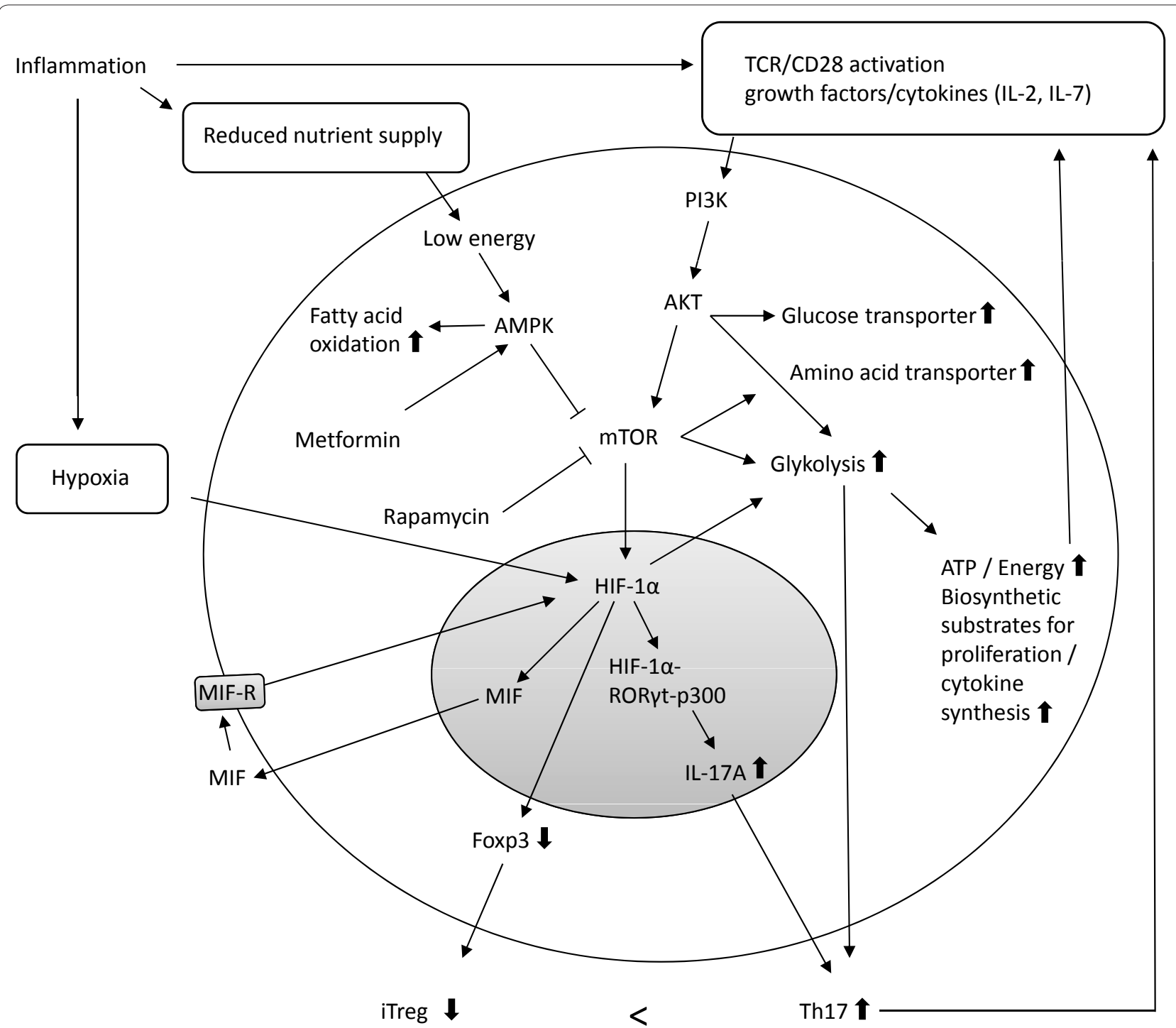

Figure 1. Metabolic pathways in T cells. T-cell activation by T-cell receptor (TCR)/CD28 co-stimulation and growth factors/cytokines such as IL-2 or IL-7 activate AKT through phosphoinositide 3-kinase (PI3K) induction in a similar manner to insulin, inducing increase of glucose uptake and glycolysis. The switch to glycolysis allows production of the requisite ATP and biosynthetic substrates that are required for proliferation, cytokine synthesis and other T-cell functions. AKT activates mammalian target of rapamycin (mTOR), which increases the expression of amino acid transporters and glycolysis. Inflammation can also lead to hypoxia and reduced nutrient supply. Low ATP levels activate AMP activated protein kinase (AMPK), which upregulates catabolic processes, such as fatty acid oxidation, and downregulates anabolic metabolism. AMPK can inhibit mTOR via raptor and lead to cell-cycle arrest. Hypoxia induces hypoxia inducible factor (HIF) expression via mTOR activity. HIF-1 forms tertiary complexes with RORYt and p300, and enhances inflammation-promoting Th17 cell development through recruitment to the IL-17 promoter or upregulation of glycolysis. Concurrently, HIF-1 attenuates inflammation-restricting regulatory T cell (Treg) development by binding Foxp3. HIF-1 induces migration inhibitory factor (MIF), which in turn causes HIF-1 expression via the MIF receptor (MIF-R) in a positive feedback loop. The AMPK stimulator metformin and the mTOR inhibitor rapaymcin are able to augment fatty acid oxidation and can increase Treg generation.

levels and joint inflammation (specifically T-cell and macrophage infiltrates and proinflammatory cytokine expression) could be demonstrated for the first time [33], and it was shown that hypoxia can be reversed by antiinflammatory treatment [34].

One principal regulator of the adaptive response to hypoxia is the transcription factor hypoxia inducible factor (HIF)-1 [28,35]. HIF-1 is a heterodimeric protein that consists of an oxygen-sensitive $\alpha$ subunit and a constitutively expressed $\beta$ subunit $[28,36]$. In nonhypoxic cells, HIF- $1 \alpha$ is continuously tagged by oxygen-dependent hydroxylation and in this way targeted for proteasomal degradation $[28,36]$. Under hypoxic conditions, however, HIF-1 is stabilized. HIF- $1 \alpha$ protein synthesis is upregulated mainly via the PI3K/mTOR pathway [37]. HIF target genes promote erythropoiesis, angiogenesis and 
Table 1. Energy/ATP-consuming functions of immune cells

\begin{tabular}{|c|c|c|}
\hline Function & ATP-dependent process & References \\
\hline \multicolumn{3}{|l|}{ Housekeeping function } \\
\hline \multirow[t]{2}{*}{ Active transport of molecules and ions } & $\mathrm{Na}^{+} \mathrm{K}^{+}$-ATPase & {$[1,79]$} \\
\hline & $\mathrm{Ca}^{2+}-$ ATPase & \\
\hline \multirow[t]{2}{*}{ Macromolecule synthesis } & Protein synthesis & {$[79,80]$} \\
\hline & RNA/DNA synthesis & \\
\hline \multicolumn{3}{|l|}{ Specific immune functions } \\
\hline \multicolumn{3}{|l|}{ Motor functions } \\
\hline Cytoskeletal rearrangement & Actomyosin-ATPase & {$[1,81]$} \\
\hline Transendothelial migration & Rho-GTPase & [82] \\
\hline \multicolumn{3}{|l|}{ Antigen processing and presentation } \\
\hline Proteasomal protein degradation (for example, 26S) & AAA-ATPases & {$[83]$} \\
\hline Antigen processing & ATP-binding cassette transporter associated with antigen processing & [84] \\
\hline Endosomal acidification & Vacuolar-type $\mathrm{H}^{+}$-ATPase & [85] \\
\hline \multicolumn{3}{|l|}{ Activation functions } \\
\hline \multirow[t]{2}{*}{ Ion pumps to restore ion gradients } & $\mathrm{Na}^{+} \mathrm{K}^{+}$-ATPase & [79] \\
\hline & $\mathrm{Ca}^{2+}-$ ATPase & \\
\hline \multirow[t]{2}{*}{ Macromolecule synthesis } & Protein synthesis & {$[79,80]$} \\
\hline & RNA/DNA synthesis & \\
\hline \multicolumn{3}{|l|}{ Effector functions } \\
\hline Perforin-based cytoxicity & Vacuolar-type H+-ATPase & {$[86]$} \\
\hline Macrophage bacterial activity & Copper-transporting ATPase & {$[87]$} \\
\hline $\begin{array}{l}\text { Macrophage membrane permeabilization and inhibition } \\
\text { of regulatory T cells }\end{array}$ & Activation of purinergic receptor $\mathrm{P} 2 \mathrm{X} 7$ by extracellular ATP $\mathrm{e}_{\mathrm{e}}$ & {$[88,89]$} \\
\hline
\end{tabular}

Data taken from [1].

vasodilatation, and HIF is a master switch to a glycolytic cell metabolism, resolving and counteracting hypoxic conditions [28].

\section{Hypoxia promotes ongoing inflammation}

Several findings indicate that HIF is involved in the persistence of inflammation and progression of neovascularization during RA. HIF is abundantly expressed in the arthritic tissue [38]. Deletion of HIF in macrophages and neutrophils resulted in a complete loss of the inflammatory response [39]. Hypoxia might also play a central role in pathogenesis of systemic sclerosis by augmenting vascular disease and tissue fibrosis [40,41]. However, HIF-1 was found to be decreased in the epidermis of systemic sclerosis patients compared with healthy controls [42], perhaps due to an increased prolyl-hydroxylase activity resulting in faster degradation of HIF-1 [41].

A recent article suggests a positive-feedback loop of HIF- $1 \alpha$ and the proinflammatory cytokine macrophage migration inhibitory factor (MIF) in human CD4+ $\mathrm{T}$ cells [36]. Hypoxia, and specifically HIF-1, is a potent and rapid inducer of MIF. In turn, MIF signaling via the MIF receptor CD74 is essential for hypoxia-mediated HIF-1 $\alpha$ expression and HIF-1 target gene induction involving ERK/mTOR activity complemented by PI3K activation upon mitogen stimulation [36]. MIF is also able to counter-regulate glucocorticoid-mediated suppression of MIF and HIF- $1 \alpha$ expression [36]. Targeting MIF and HIF may thus be effective in disrupting self-maintaining inflammation.

\section{Hypoxia and glycolysis control the balance of Th17 cells/ regulatory $\mathrm{T}$ cells}

The differentiation of naïve CD4 cells into Th1 and Th17 subsets of T-helper cells is selectively regulated by signaling from mTORC1 that is dependent on the small GTPase Rheb [43]. Interestingly, CD4 ${ }^{+} \mathrm{T}$-cell subsets require distinct metabolic programs [44]. Th1, Th2 and Th17 cells express high surface levels of the glucose transporter Glut1 and switch on a highly glycolytic program. In contrast, regulatory $\mathrm{T}$ cells (Tregs) express low levels of Glut1 and have high lipid oxidation rates [44]. In an asthma model, AMPK stimulation was sufficient to decrease Glut1 and increase Treg generation, indicating that the distinct metabolic programs can be modulated in vivo [44]. Recently, persistent hypoxia and glycolysis were demonstrated to control the balance 
between inflammation-promoting Th17 cells and inflammation-restricting Tregs $[9,45]$.

Hypoxia-induced HIF expression exerts a direct transcriptional activation of RORyt, a master regulator of Th17 cell differentiation, and recruitment to the IL-17 promoter via tertiary complex formation with ROR $\gamma \mathrm{t}$ and p300 (Figure 1) $[9,45]$. Concurrently, HIF-1 attenuates induced Treg development by binding Foxp3, a key transcription factor that promotes the Treg lineage, via a proposed ubiquitination pathway $[9,45]$. Mice with HIF$1 \alpha$-deficient T cells are resistant to induction of Th17dependent experimental autoimmune encephalitis, associated with diminished Th17 cells and increased Tregs, indicating the therapeutic potential of HIF modulation. Similar to these findings, another study suggested that HIF- $1 \alpha$ is involved in differentiation of Th17 cells and Tregs, but ascribed the role of HIF-1a to upregulation of glycolysis and not as a direct effect of HIF-1a on ROR $\gamma \mathrm{t}$ and Foxp3 $[9,46]$. Supporting the concept that hypoxia and IL-17A are key mediators in inflammatory arthritis, patients with lower tissue partial pressure of oxygen $<20 \mathrm{mmHg}$ have been demonstrated to have increased IL-17A positive mononuclear cells [47]. Tumor hypoxia appears to be different, as it has been reported to inhibit T-cell proliferation and cytokine secretion and to activate Tregs [48].

Glycolysis has been suggested to play a role in the pathogenesis of RA [49]. The activity levels of two major enzymes of the glycolytic pathway - glyceraldehyde 3-phosphate dehydrogenase and lactate dehydrogenase were increased in RA synovial cells [50]. However, clear studies of a direct relationship of increased glycolytic activity and inflammation are lacking. It is striking that several glycolytic enzymes such as glucose-6-phosphate isomerase, enolase, aldolase and triose phosphate isomerase act as autoantigens [49]; however, their role in RA remains unclear $[49,51,52]$.

Rapamycin (also known as sirolimus) is an mTOR inhibitor used in transplantation medicine. This inhibitor acts similar to the immunosuppressant FK506 (tacrolimus) by binding to the intracellular immunophilin FKbinding protein 12 (FKBP12). Unlike the FK506-FKBP12 complex that inhibits calcineurin, however, the rapamycin-FKBP12 complex interferes with the function of mTOR. Rapamycin has been found effective for systemic lupus erythematosus and systemic sclerosis in animal models and pilot clinical trials [53-57]. Tregs can be expanded by rapamycin in vitro [58] and were found to suppress colitis in an experimental mouse model [59].

\section{Metabolic signals regulate differentiation of memory CD8 $T$ cells and interfere with innate immunity}

In addition to their more established roles in nutrient responses, AKT1 to AKT3, AMPK, and LKB1 are suggested to also control the fate switch from cytotoxic effector to memory $\mathrm{CD} 8^{+} \mathrm{T}$ cells $[3,5]$. It was proposed that, following the peak of the primary $\mathrm{T}$-cell response to infection, $\mathrm{T}$ cells experience metabolic stress - perhaps due to nutrient and/or growth factor limitation as infection is cleared and antigen concentrations decline and cells need to switch from glycolysis to other forms of catabolism, such as fatty acid oxidation, in order to survive and develop into memory $\mathrm{T}$ cells $[6,60,61]$. Treatment of mice after infection with either the mTOR inhibitor rapaymcin or the AMPK stimulator metformin, two drugs that augment fatty acid oxidation, enhanced the development of memory CD8 T cells $[6,60,61]$.

Similar to $\mathrm{T}$ cells, dendritic cells were recently shown upon activation by Toll-like receptors to switch from oxidative phosphorylation to glycolysis [62]. This metabolic switch depends on the PI3K/AKT pathway, is antagonized by AMPK, and is required for dendritic cell maturation [62]. The molecular basis of increased glycolysis in response to Toll-like receptor activation is poorly understood but might be linked to expression of 6-phosphofructo-2-kinase/fructose-2,6-biphosphatase or HIF- $1 \alpha[7,63,64]$. Activation of macrophages by IFN $\gamma$ and lipopolysaccharide inhibits mitochondrial respiration by release of large quantities of nitric oxide produced by the inducible nitric oxide synthase [65]. In monocytes/ macrophages, hypoxia can prolong the survival of these cells - most probably by enhancing glycolysis [66]. Furthermore, monocytes begin to acquire a glycolytic metabolism during differentiation into macrophages, with possible significance for the ability of tissue macrophages to adapt to hypoxia [66]. Prolongation of survival by hypoxia has also been found for human neutrophils $[67,68]$.

NOD-like receptors are involved in the recognition of host-derived and microbial danger-associated molecules that lead to the assembly of high-molecular-mass complexes called inflammasomes and the subsequent generation of active caspase 1 , a requisite for the production of the inflammatory cytokine IL-1 $\beta$ [7]. Recently, the NLRP3 inflammasome has been shown to cause insulin resistance in the periphery and may be important for the pathogenesis of type 2 diabetes $[7,69]$. It is under discussion whether the NLRP3/IL-1 system might cause insulin resistance in order to prevent generation of damaging metabolites of glucose metabolism, or to spare glucose for leukocyte function in immune cells [7], suggesting metabolic sequelae of an energy appeal reaction also on the cellular level (see below).

In contrast to metabolic changes, which occur locally in cells and tissue - for example, due to hypoxia at the site of inflammation - interesting metabolic changes can also occur systemically. Circulating peripheral blood 
cells, such as $\mathrm{T}$ cells, display oxidative stress due to depletion of glutathione in systemic lupus erythematosus [70]. Levels of surface thiols and intracellular glutathione of leukocytes are significantly lower in RA patients [71]. Excessive production of reactive oxygen species disturbs the redox status and can modulate the expression of inflammatory chemokines, leading to inflammatory processes [72]. Such differences in metabolism may represent a clear distinction between localized and systemic autoimmune inflammatory diseases.

\section{Energy metabolism in the body and consequence for chronic inflammatory diseases} Energy metabolism: the systemic function

Energy metabolism is not only a question for a single cell or a group of cells such as, for example, T cells or muscle cells, because provision and allocation of energy-rich fuels involves the entire body. Need for energy-rich substrates at a certain location in the body can induce a systemic response if local stores are not sufficient to provide necessary supplies. The systemic response redirects energy-rich fuels from stores to the site of action, the consumers [2].

Such a redirection program can be started by a voluntary act when an individual decides to use muscles during exercise. In such a situation, the central nervous system activates, among others, the sympathetic nervous system (adrenaline, noradrenaline), the hypothalamic-pituitaryadrenal axis (cortisol), and the hypothalamic-pituitarysomatic axis (growth hormone, insulin-like growth factor-1), which induce gluconeogenesis, glycogenolysis, and lipolysis. This is supported by release of IL- 6 from muscles into systemic circulation, which helps activate the redirection program [73]. Redirection of energy-rich substrates from storage sites to consumer can be called the energy appeal reaction.

If the immune system needs energy-rich fuels in the context of infection or other forms of activation, a similar energy appeal reaction is prompted [2]. The response is a concerted action of the neuroendocrine immune network. But does the activated immune system need a lot of energy? Table 2 presents the energy demand of the entire body, systems, and organs. Obviously, the immune system needs a lot of energy, particularly in an activated state. In an inflammatory situation, the energy appeal reaction is driven by cytokine-induced stimulation of the central nervous system, endocrine organs, and energy storage organs such as the liver, muscles, and fat tissue [2]. IL-6 is a classical candidate that can activate these remote places (but also IFN $\gamma$, IFN $\alpha$, IL-2, TNF, and others [2]).

The question remains whether this seemingly adaptive program has been positively selected in the context of CIDs such as RA or systemic lupus erythematosus.
Table 2. Energy expenditure of systems and organs under various conditions

\begin{tabular}{|c|c|}
\hline System/organ & $\begin{array}{l}\text { Energy expenditure } \\
\text { per day }(\mathrm{kJ} / \text { day })^{\mathrm{a}}\end{array}$ \\
\hline Total body basal metabolic rate & 7,000 \\
\hline Total body metabolic rate with usual activity & 10,000 \\
\hline Total body metabolic rate during minor surgery & 11,000 \\
\hline Total body metabolic rate with multiple bone fractures & Up to 13,000 \\
\hline Total body metabolic rate with sepsis & 15,000 \\
\hline Total body metabolic rate with extensive burns & 20,000 \\
\hline Total body daily uptake (absorptive capacity in the gut) & 20,000 \\
\hline Immune system metabolic rate under normal conditions & $1,600^{b}$ \\
\hline Immune system metabolic rate moderately activated & $2,100^{b}$ \\
\hline Central nervous system metabolic rate & 2,000 \\
\hline Muscle metabolic rate at rest & 2,500 \\
\hline Muscle metabolic rate activated & $\begin{array}{l}2,000 \text { to } 10,000 \\
\text { and more }\end{array}$ \\
\hline Liver ${ }^{c}$ metabolic rate & 1,600 \\
\hline Kidney metabolic rate & 600 \\
\hline Gastrointestinal tract ${ }^{c}$ metabolic rate & 1,000 \\
\hline Abdominal organ (together) ${ }^{c}$ metabolic rate & 3,000 to 3,700 \\
\hline Lung $^{c}$ metabolic rate & 400 \\
\hline Heart metabolic rate & $\begin{array}{l}1,100 \text { (and more } \\
\text { when activated) }\end{array}$ \\
\hline
\end{tabular}

\section{Evolutionary medicine, chronic inflammatory disease, and} energy demand

The evolutionary principle of replication with variation and selection is undeniably fundamental and has history. This is a successful history of positive selection, which can only happen under circumstances of unrestricted gene transfer to offspring. The hypothesis is that genes which play a specific role in CIDs were not positively and specifically selected for a CID because unrestricted gene transfer was not possible in CIDs $[2,74]$. If this is correct, regulatory mechanisms of the neuroendocrine immune network did not evolve to cope with CIDs. Instead, the neuroendocrine immune network was positively selected in the context of nonlife-threatening transient inflammatory episodes such as, for example, infection or wound healing. These episodes are usually short lived and do not last longer than 3 to 6 weeks. No prolonged adaptive program specifically exists for CIDs.

Similarly, the abovementioned energy appeal reaction as a consequence of systemic cytokine stimulation has been positively selected for transient nonlife-threatening inflammatory episodes [2,74]. 
Table 3. The energy appeal reaction

\begin{tabular}{|c|c|c|}
\hline Known reaction & $\begin{array}{l}\text { Physiological meaning in transient } \\
\text { inflammatory episodes }\end{array}$ & $\begin{array}{l}\text { Pathophysiological problem in chronic } \\
\text { inflammatory diseases }\end{array}$ \\
\hline Fatigue & $\begin{array}{l}\text { Stop of energy expenditure for brain and muscles, } \\
\text { stop of courtship and foraging behavior }\end{array}$ & $\begin{array}{l}\text { Depressive symptoms/longstanding fatigue (sickness } \\
\text { behavior) }\end{array}$ \\
\hline Anorexia & Stop of energy expenditure for gut function & Reduced or stopped uptake of energy-rich substrates \\
\hline Malnutrition & Stop of energy expenditure for gut function & $\begin{array}{l}\text { Reduced or stopped uptake of vitamins and trace } \\
\text { elements }{ }^{\mathrm{a}}\end{array}$ \\
\hline Muscle breakdown & $\begin{array}{l}\text { Stop of energy expenditure for muscles, and } \\
\text { redirection of muscle proteins to gluconeogenesis }\end{array}$ & Cachexia \\
\hline Increased muscle relative to fat breakdown & $\begin{array}{l}\text { Stop of energy expenditure for muscles, and } \\
\text { redirection of muscle proteins to gluconeogenesis }\end{array}$ & Cachectic obesity \\
\hline $\begin{array}{l}\text { Insulin (insulin-like growth factor-1) resistance } \\
\text { in liver, muscle, and fat tissue }\end{array}$ & $\begin{array}{l}\text { Redirection of glucose and free fatty acids to immune } \\
\text { cells, which do not become insulin (insulin-like } \\
\text { growth factor-1) resistant }\end{array}$ & Insulin resistance as part of the metabolic syndrome \\
\hline $\begin{array}{l}\text { Appearance of a proinflammatory form of } \\
\mathrm{HDL} \text { cholesterol }\end{array}$ & $\begin{array}{l}\text { Acute-phase reaction of lipid metabolism leading } \\
\text { to higher delivery of cholesterol and other lipids to } \\
\text { macrophages }\end{array}$ & Dyslipidemia as part of the metabolic syndrome \\
\hline Alterations of steroid hormone axes & $\begin{array}{l}\text { Cytokine/leptin-driven hypoandrogenemia } \\
\text { supports muscle breakdown and protein delivery } \\
\text { for gluconeogenesis and support of an activated } \\
\text { immune system (alanine, glutamine) }\end{array}$ & $\begin{array}{l}\text { Cortisol-to-androgen preponderance in chronic } \\
\text { inflammation is catabolic and gluconeogenetic }\end{array}$ \\
\hline $\begin{array}{l}\text { Elevated sympathetic tone and local } \\
\text { sympathetic nerve fiber loss, decreased } \\
\text { parasympathetic tone }\end{array}$ & $\begin{array}{l}\text { Cytokine-driven increase of sympathetic nervous } \\
\text { system activity increases gluconeogenesis and } \\
\text { lipolysis. The parallel loss of sympathetic nerve fibers } \\
\text { in inflamed tissue supports local inflammation and } \\
\text { local lipolysis }\end{array}$ & Hypertension as part of the metabolic syndrome \\
\hline Increase of body water & $\begin{array}{l}\text { Cytokine-driven activation of the water retention } \\
\text { system due to systemic water loss during } \\
\text { inflammation }\end{array}$ & Hypertension as part of the metabolic syndrome \\
\hline Inflammation-related anemia & $\begin{array}{l}\text { Stop of energy expenditure for brain and muscle } \\
\text { activity }\end{array}$ & Anemia \\
\hline $\begin{array}{l}\text { Inflammation-related provision of calcium } \\
\text { and phosphorus }\end{array}$ & $\begin{array}{l}\text { High calcium and phosphorus are mandatory for } \\
\text { energy-consuming reactions (think of ATP) }\end{array}$ & Local and general osteopenia \\
\hline
\end{tabular}

Data taken from $[2,90]$. HDL, high-density lipoprotein. aHypovitaminosis $D$ and others, deficiency in zinc, iron, copper, magnesium, and similar.

Furthermore, genes that are associated with CIDs have been positively selected independent of CIDs. The theory of antagonistic pleiotropy - formulated by Williams in the 1950s - similarly applies to CIDs [2,75]. This theory suggests that genes associated with CIDs have been positively selected to improve survival at younger ages and to stimulate reproduction independent of CIDs. Recent delineation shows that several CID risk genes have a pleiotropic meaning outside CIDs at younger ages [76].

\section{The energy appeal reaction and disease sequelae}

Organisms evolved under conditions that favored the development of complex mechanisms for obtaining food and for storage and allocation of energy-rich fuels. Energy regulation and cellular bioenergetics take the highest position in the hierarchy of homeostatic control. The main supporters of energy-rich fuel storage in liver, muscle, and adipose tissue are insulin, insulin-like growth factor 1, androgens/estrogens, and the parasympathetic nervous system. We can call them storing factors. In contrast, provision of energy-rich fuels to the entire body in the form of glucose, protein, and fatty acids is mainly supported by mediator substances of the sympathetic nervous system, the hypothalamic-pituitary-hormonal axes (cortisol and growth hormone), and the pancreas (glucagon). We can call them provision factors. Table 3 describes particular aspects of the neuroendocrine immune response linking it to the energy appeal reaction.

The energy appeal reaction is not an unspecific fightor-flight response in the sense of Hans Selye, but an adaptive program. If the adaptive program is used too long, real problems can appear that are a consequence of worn-out regulation. That exhausted regulation really exists is substantiated by the fact that patients on ICUs with severe activation of the stress system sometimes suffer from lifelong adrenal insufficiency even after overall recovery [77]. 
A longstanding reallocation program can thus lead to acute and chronic disease sequelae as mentioned in Table 3. The framework explains that CID sequelae are a consequence of a continuous energy appeal reaction. The systemic response of the body - the energy appeal reaction - is important to support the immune system during short-lived inflammatory episodes, but its continuous use in CIDs is highly unfavorable.

Since disease sequelae are a significant part of clinical CID, etiology of disease sequelae is also part of CID etiology. It becomes understandable that long-term changes of the neuroendocrine immune network as a consequence of a chronic energy appeal reaction are also part of etiological considerations. We conclude that among genetic issues, environmental factors (microbes, toxins, drugs, injuries, radiation, cultural background, and geography), exaggerated immune and wound responses, and irrecoverable tissue destruction, changes of the neuroendocrine immune network in the context of a prolonged energy appeal reaction become a fifth factor of CID etiology [78].

\section{Conclusions}

Metabolic pathways drive an energy appeal reaction for the immune response on cellular and organism levels. However, if the immune response is not sufficient to resolve inflammation, the metabolic programs can support ongoing chronic inflammation and lead to metabolic disease sequelae. This suggests chronic inflammation to be powered by energy metabolism, indicating that energy metabolism is a promising therapeutic target.

\begin{abstract}
Abbreviations
AMPK, AMP activated protein kinase; CID, chronic inflammatory disease; FKBP12, immunophilin FK506-binding protein; Glut glucose transporter; HIF, hypoxia inducible factor; IFN, interferon; IL, interleukin; mTOR, mammalian target of rapamycin; mTORC, mammalian target of rapamycin complex; MIF, migration inhibitory factor; OXPHOS, oxidative phosphorylation; PI3K, phosphoinositide 3-kinase; RA, rheumatoid arthritis; Th, T-helper type; TNF, tumor necrosis factor; Treg, regulatory T cell.
\end{abstract}

\section{Competing interests}

The authors declare that they have no competing interests.

\section{Author contributions}

CMS and FB mainly contributed to the first part of the manuscript (cellular energy metabolism), and RHS mainly contributed to the second part of the manuscript (energy metabolism in the body and consequence for chronic inflammatory diseases).

\section{Author details}

'Department of Rheumatology and Clinical Immunology, Charité University Medicine Berlin, Charitéplatz 1, 10117 Berlin, Germany. ${ }^{2}$ Laboratory of Experimental Rheumatology and Neuroendocrino-Immunology, Department of Internal Medicine I, University Hospital Regensburg, Franz-Josef-StraussAllee 11, 93053 Regensburg, Germany.

Published: 29 June 2012

\section{References}

1. Buttgereit $F$, Burmester GR, Brand MD: Bioenergetics of immune functions: fundamental and therapeutic aspects. Immunol Today 2000, 21:192-199.

2. Straub $\mathrm{RH}$, Cutolo $\mathrm{M}$, Buttgereit $\mathrm{F}$, Pongratz $\mathrm{G}$ : Energy regulation and neuroendocrine-immune control in chronic inflammatory diseases. J Intern Med 2010, 267:543-560.

3. Finlay D, Cantrell DA: Metabolism, migration and memory in cytotoxic T cells. Nat Rev Immunol 2011, 11:109-117.

4. Fox CJ, Hammerman PS, Thompson CB: Fuel feeds function: energy metabolism and the T-cell response. Nat Rev Immunol 2005, 5:844-852.

5. Mathis D, Shoelson SE: Immunometabolism: an emerging frontier. Nat Rev Immunol 2011, 11:81-83.

6. Pearce EL: Metabolism in T cell activation and differentiation. Curr Opin Immunol 2010, 22:314-320.

7. Tannahill GM, O'Neill LA: The emerging role of metabolic regulation in the functioning of Toll-like receptors and the NOD-like receptor NIrp3. FEBS Lett 2011, 585:1568-1572.

8. Inoki K, Kim J, Guan KL: AMPK and mTOR in cellular energy homeostasis and drug targets. Annu Rev Pharmacol Toxicol 2012, 52:381-400.

9. Nutsch K, Hsieh C: When T cells run out of breath: the HIF-1a story. Cell 2011, 146:673-674

10. Powell JD, Pollizzi KN, Heikamp EB, Horton MR: Regulation of immune responses by mTOR. Annu Rev Immunol 2011, 30:39-68.

11. Procaccini C, Galgani M, De Rosa V, Matarese G: Intracellular metabolic pathways control immune tolerance. Trends Immuno/ 2012, 33:1-7.

12. Gatza E, Wahl DR, Opipari AW, Sundberg TB, Reddy P, Liu C, Glick GD, Ferrara $J$ : Manipulating the bioenergetics of alloreactive T cells causes their selective apoptosis and arrests graft-versus-host disease. Sci Trans/Med 2011, 3:67ra68

13. Jones RG, Thompson CB: Revving the engine: signal transduction fuels T cell activation. Immunity 2007, 27:173-178.

14. Vander Heiden MG, Cantley LC, Thompson CB: Understanding the Warburg effect: the metabolic requirements of cell proliferation. Science 2009, 324:1029-1033.

15. Summers SA, Yin VP, Whiteman EL, Garza LA, Cho H, Tuttle RL, Birnbaum MJ: Signaling pathways mediating insulin-stimulated glucose transport. Ann N Y Acad Sci 1999, 892:169-186.

16. Frauwirth KA, Riley JL, Harris MH, Parry RV, Rathmell JC, Plas DR, Elstrom RL, June $\mathrm{CH}$, Thompson CB: The CD28 signaling pathway regulates glucose metabolism. Immunity 2002, 16:769-777.

17. Wofford JA, Wieman HL, Jacobs SR, Zhao Y, Rathmell JC: IL-7 promotes Glut1 trafficking and glucose uptake via STAT5-mediated activation of Akt to support T-cell survival. Blood 2008, 111:2101-2111.

18. Frauwirth KA, Thompson CB: Regulation of T lymphocyte metabolism. J Immunol 2004, 172:4661-4665.

19. Gingras AC, Raught B, Sonenberg N: Regulation of translation initiation by FRAP/mTOR. Genes Dev 2001, 15:807-826.

20. Hay N, Sonenberg N: Upstream and downstream of mTOR. Genes Dev 2004, 18:1926-1945

21. Duvel K, Yecies JL, Menon S, Raman P, Lipovsky Al, Souza AL, Triantafellow E, Ma Q, Gorski R, Cleaver S, Vander Heiden MG, MacKeigan JP, Finan PM, Clish CB, Murphy LO, Manning BD: Activation of a metabolic gene regulatory network downstream of mTOR complex 1. Mol Cell 2010, 39:171-183.

22. Ghillebert R, Swinnen E, Wen J, Vandesteene L, Ramon M, Norga K, Rolland F, Winderickx J: The AMPK/SNF1/SnRK1 fuel gauge and energy regulator: structure, function and regulation. FEBS J 2011, 278:3978-3990.

23. Hardie DG: AMP-activated protein kinase: an energy sensor that regulates all aspects of cell function. Genes Dev 2011, 25:1895-1908.

24. Gwinn DM, Shackelford DB, Egan DF, Mihaylova MM, Mery A, Vasquez DS, Turk BE, Shaw RJ: AMPK phosphorylation of raptor mediates a metabolic checkpoint. Mol Cell 2008, 30:214-226.

25. Huang W, Ramsey KM, Marcheva B, Bass J: Circadian rhythms, sleep, and metabolism. J Clin Invest 2011, 121:2133-2141.

26. Lamia KA, Sachdeva UM, DiTacchio L, Williams EC, Alvarez JG, Egan DF, Vasquez DS, Juguilon H, Panda S, Shaw RJ, Thompson CB, Evans RM: AMPK regulates the circadian clock by cryptochrome phosphorylation and degradation. Science 2009, 326:437-440.

27. Dziurla R, Gaber T, Fangradt M, Hahne M, Tripmacher R, Kolar P, Spies CM, Burmester GR, Buttgereit F: Effects of hypoxia and/or lack of glucose on cellular energy metabolism and cytokine production in stimulated human CD4+ T lymphocytes. Immunol Lett 2010, 131:97-105. 
28. Gaber T, Dziurla R, Tripmacher R, Burmester GR, Buttgereit F: Hypoxia inducible factor (HIF) in rheumatology: low $\mathrm{O}_{2}$ ! See what HIF can do! Ann Rheum Dis 2005, 64:971-980.

29. Tripmacher R, Gaber T, Dziurla R, Haupl T, Erekul K, Grutzkau A, Tschirschmann M, Scheffold A, Radbruch A, Burmester GR, Buttgereit F: Human CD4 ${ }^{+} T$ cells maintain specific functions even under conditions of extremely restricted ATP production. Eur J Immunol 2008, 38:1631-1642.

30. Falchuk KH, Goetzl EJ, Kulka JP: Respiratory gases of synovial fluids. An approach to synovial tissue circulatory-metabolic imbalance in rheumatoid arthritis. Am J Med 1970, 49:223-231.

31. Lund-Olesen K: Oxygen tension in synovial fluids. Arthritis Rheum 1970, 13:769-776.

32. Sivakumar B, Akhavani MA, Winlove CP, Taylor PC, Paleolog EM, Kang N: Synovial hypoxia as a cause of tendon rupture in rheumatoid arthritis. J Hand Surg Am 2008, 33:49-58.

33. Ng CT, Biniecka M, Kennedy A, McCormick J, Fitzgerald O, Bresnihan B, Buggy D, Taylor CT, O'Sullivan J, Fearon U, Veale DJ: Synovial tissue hypoxia and inflammation in vivo. Ann Rheum Dis 2010, 69:1389-1395.

34. Kennedy A, Ng CT, Chang TC, Biniecka M, O'Sullivan JN, Heffernan E, Fearon U, Veale DJ: Tumor necrosis factor blocking therapy alters joint inflammation and hypoxia. Arthritis Rheum 2011, 63:923-932.

35. Wang GL, Semenza GL: Characterization of hypoxia-inducible factor 1 and regulation of DNA binding activity by hypoxia. J Biol Chem 1993, 268:21513-21518.

36. Gaber T, Schellmann S, Erekul KB, Fangradt M, Tykwinska K, Hahne M, Maschmeyer P, Wagegg M, Stahn C, Kolar P, Dziurla R, Lohning M, Burmester $G R$, Buttgereit F: Macrophage migration inhibitory factor counterregulates dexamethasone-mediated suppression of hypoxia-inducible factor-1 alpha function and differentially influences human $\mathrm{CD} 4^{+} \mathrm{T}$ cell proliferation under hypoxia. J Immuno/ 2011, 186:764-774.

37. Nakamura $\mathrm{H}$, Makino Y, Okamoto K, Poellinger $\mathrm{L}$, Ohnuma $\mathrm{K}$, Morimoto $\mathrm{C}$, Tanaka H: TCR engagement increases hypoxia-inducible factor-1 alpha protein synthesis via rapamycin-sensitive pathway under hypoxic conditions in human peripheral T cells. J Immuno/ 2005, 174:7592-7599.

38. Hollander AP, Corke KP, Freemont AJ, Lewis CE: Expression of hypoxiainducible factor 1 a by macrophages in the rheumatoid synovium: implications for targeting of therapeutic genes to the inflamed joint. Arthritis Rheum 2001, 44:1540-1544.

39. Cramer T, Yamanishi Y, Clausen BE, Forster I, Pawlinski R, Mackman N, Haase VH, Jaenisch R, Corr M, Nizet V, Firestein GS, Gerber HP, Ferrara N, Johnson RS: HIF-1alpha is essential for myeloid cell-mediated inflammation. Cell 2003, 112:645-657.

40. van Hal TW, van Bon L, Radstake TR: A system out of breath: how hypoxia possibly contributes to the pathogenesis of systemic sclerosis. Int Rheumato/ 2011, 2011:Article ID 824972, 1-7.

41. Beyer C, Schett G, Gay S, Distler O, Distler JH: Hypoxia. Hypoxia in the pathogenesis of systemic sclerosis. Arthritis Res Ther 2009, 11:220.

42. Distler O, Distler JH, Scheid A, Acker T, Hirth A, Rethage J, Michel BA, Gay RE, Muller-Ladner U, Matucci-Cerinic M, Plate KH, Gassmann M, Gay S: Uncontrolled expression of vascular endothelial growth factor and its receptors leads to insufficient skin angiogenesis in patients with systemic sclerosis. Circ Res 2004, 95:109-116.

43. Delgoffe GM, Pollizzi KN, Waickman AT, Heikamp E, Meyers DJ, Horton MR, Xiao B, Worley PF, Powell JD: The kinase mTOR regulates the differentiation of helper T cells through the selective activation of signaling by MTORC1 and mTORC2. Nat Immunol 2011, 12:295-303.

44. Michalek RD, Gerriets VA, Jacobs SR, Macintyre AN, Maclver NJ, Mason EF, Sullivan SA, Nichols AG, Rathmell JC: Cutting edge: distinct glycolytic and lipid oxidative metabolic programs are essential for effector and regulatory $\mathrm{CD}^{+}{ }^{+} \mathrm{T}$ cell subsets. J Immuno/ 2011, 186:3299-3303.

45. Dang EV, Barbi J, Yang HY, Jinasena D, Yu H, Zheng Y, Bordman Z, Fu J, Kim Y, Yen HR, Luo W, Zeller K, Shimoda L, Topalian SL, Semenza GL, Dang CV, Pardoll DM, Pan F: Control of T(H)17/T(reg) balance by hypoxia-inducible factor 1. Cell 2011, 146:772-784

46. Shi LZ, Wang R, Huang G, Vogel P, Neale G, Green DR, Chi H: HIF1adependent glycolytic pathway orchestrates a metabolic checkpoint for the differentiation of TH17 and Treg cells. J Exp Med 2011, 208:1367-1376.

47. Moran EM, Heydrich R, Ng CT, Saber TP, McCormick J, Sieper J, Appel H, Fearon U, Veale DJ: IL-17A expression is localised to both mononuclear and polymorphonuclear synovial cell infiltrates. PLoS One 2011, 6:e24048.

48. Sitkovsky MV, Kjaergaard J, Lukashev D, Ohta A: Hypoxia-adenosinergic immunosuppression: tumor protection by T regulatory cells and cancerous tissue hypoxia. Clin Cancer Res 2008, 14:5947-5952.

49. Chang X, Wei C: Glycolysis and rheumatoid arthritis. Int J Rheum Dis 2011 $14: 217-222$.

50. Henderson B, Bitensky L, Chayen J: Glycolytic activity in human synovial lining cells in rheumatoid arthritis. Ann Rheum Dis 1979, 38:63-67.

51. Matsumoto I, Lee DM, Goldbach-Mansky R, Sumida T, Hitchon CA, Schur PH, Anderson RJ, Coblyn JS, Weinblatt ME, Brenner M, Duclos B, Pasquali JL, ElGabalawy H, Mathis D, Benoist C: Low prevalence of antibodies to glucose6-phosphate isomerase in patients with rheumatoid arthritis and a spectrum of other chronic autoimmune disorders. Arthritis Rheum 2003, 48:944-954.

52. Matsumoto I, Staub A, Benoist C, Mathis D: Arthritis provoked by linked T and B cell recognition of a glycolytic enzyme. Science 1999, 286:1732-1735.

53. Fernandez D, Bonilla E, Mirza N, Niland B, Perl A: Rapamycin reduces disease activity and normalizes T cell activation-induced calcium fluxing in patients with systemic lupus erythematosus. Arthritis Rheum 2006, 54:2983-2988

54. Warner LM, Adams LM, Sehgal SN: Rapamycin prolongs survival and arrests pathophysiologic changes in murine systemic lupus erythematosus. Arthritis Rheum 1994, 37:289-297.

55. Fernandez D, Perl A: mTOR signaling: a central pathway to pathogenesis in systemic lupus erythematosus? Discov Med 2010, 9:173-178.

56. Yoshizaki A, Yanaba K, Iwata Y, Komura K, Ogawa F, Takenaka M, Shimizu K, Asano Y, Hasegawa M, Fujimoto M, Sato S: Treatment with rapamycin prevents fibrosis in tight-skin and bleomycin-induced mouse models of systemic sclerosis. Arthritis Rheum 2010, 62:2476-2487.

57. SuTI, Khanna D, Furst DE, Danovitch G, Burger C, Maranian P, Clements PJ: Rapamycin versus methotrexate in early diffuse systemic sclerosis: results from a randomized, single-blind pilot study. Arthritis Rheum 2009, 60:3821-3830

58. Qu Y, Zhang B, Zhao L, Liu G, Ma H, Rao E, Zeng C, Zhao Y: The effect of immunosuppressive drug rapamycin on regulatory $\mathrm{CD} 4^{+} \mathrm{CD} 25^{+} \mathrm{Foxp} 3^{+}$ T cells in mice. Transpl Immuno/ 2007, 17:153-161

59. Ogino H, Nakamura K, Iwasa T, Ihara E, Akiho H, Motomura Y, Akahoshi K, Igarashi H, Kato M, Kotoh K, Ito T, Takayanagi R: Regulatory T cells expanded by rapamycin in vitro suppress colitis in an experimental mouse model. J Gastroenterol 2011, 47:366-376.

60. Araki K, Turner AP, Shaffer VO, Gangappa S, Keller SA, Bachmann MF, Larsen CP, Ahmed R: mTOR regulates memory CD8 T-cell differentiation. Nature 2009, 460:108-112

61. Pearce EL, Walsh MC, Cejas PJ, Harms GM, Shen H, Wang LS, Jones RG, Choi Y Enhancing CD8 T-cell memory by modulating fatty acid metabolism. Nature 2009, 460:103-107

62. Krawczyk CM, Holowka T, Sun J, Blagih J, Amiel E, DeBerardinis RJ, Cross JR, Jung E, Thompson CB, Jones RG, Pearce EJ: Toll-like receptor-induced changes in glycolytic metabolism regulate dendritic cell activation. Blood 2010, 115:4742-4749.

63. Kim SY, Choi YJ, Joung SM, Lee BH, Jung YS, Lee JY: Hypoxic stress upregulates the expression of Toll-like receptor 4 in macrophages via hypoxia-inducible factor. Immunology 2010, 129:516-524.

64. Rodriguez-Prados JC, Traves PG, Cuenca J, Rico D, Aragones J, Martin-Sanz P, Cascante M, Bosca L: Substrate fate in activated macrophages: a comparison between innate, classic, and alternative activation. J Immunol 2010, 185:605-614

65. Garedew A, Moncada S: Mitochondrial dysfunction and HIF1alpha stabilization in inflammation. J Cell Sci 2008, 121:3468-3475.

66. Roiniotis J, Dinh H, Masendycz P, Turner A, Elsegood CL, Scholz GM, Hamilton JA: Hypoxia prolongs monocyte/macrophage survival and enhanced glycolysis is associated with their maturation under aerobic conditions. J Immunol 2009, 182:7974-7981.

67. Hannah S, Mecklenburgh K, Rahman I, Bellingan GJ, Greening A, Haslett C, Chilvers ER: Hypoxia prolongs neutrophil survival in vitro. FEBS Lett 1995, 372:233-237.

68. Walmsley SR, Print C, Farahi N, Peyssonnaux C, Johnson RS, Cramer T, Sobolewski A, Condliffe AM, Cowburn AS, Johnson N, Chilvers ER: Hypoxiainduced neutrophil survival is mediated by HIF-1a-dependent NF-KB activity. J Exp Med 2005, 201:105-115.

69. Vandanmagsar B, Youm YH, Ravussin A, Galgani JE, Stadler K, Mynatt RL, Ravussin E, Stephens JM, Dixit VD: The NLRP3 inflammasome instigates 
obesity-induced inflammation and insulin resistance. Nat Med 2011, 17:179-188.

70. Gergely P, Jr, Grossman C, Niland B, Puskas F, Neupane H, Allam F, Banki K, Phillips PE, Perl A: Mitochondrial hyperpolarization and ATP depletion in patients with systemic lupus erythematosus. Arthritis Rheum 2002, 46:175-190

71. Pedersen-Lane JH, Zurier RB, Lawrence DA: Analysis of the thiol status of peripheral blood leukocytes in rheumatoid arthritis patients. J Leukoc Biol 2007, 81:934-941.

72. Shah D, Wanchu A, Bhatnagar A: Interaction between oxidative stress and chemokines: possible pathogenic role in systemic lupus erythematosus and rheumatoid arthritis. Immunobiology 2011, 216:1010-1017.

73. Pedersen BK: Exercise-induced myokines and their role in chronic diseases. Brain Behav Immun 2011, 25:811-816.

74. Straub RH, Besedovsky HO: Integrated evolutionary, immunological, and neuroendocrine framework for the pathogenesis of chronic disabling inflammatory diseases. FASEB J 2003, 17:2176-2183.

75. Williams GC: Pleiotropy, natural selection, and the evolution of senescence. Evolution 1957, 11:398-411.

76. Straub RH: [Neuroendocrine immunology: new pathogenetic aspects and clinical application]. Z Rheumato/ 2011, 70:767-774

77. Cooper MS, Stewart PM: Corticosteroid insufficiency in acutely ill patients. NEngl J Med 2003, 348:727-734.

78. Straub $\mathrm{RH}$ : Concepts of evolutionary medicine and energy regulation contribute to the etiology of systemic chronic inflammatory diseases. Brain Behav Immun 2011, 25:1-5.

79. Buttgereit F, Brand MD, Muller M: ConA induced changes in energy metabolism of rat thymocytes. Biosci Rep 1992, 12:381-386.

80. Princiotta MF, Finzi D, Qian SB, Gibbs J, Schuchmann S, Buttgereit F, Bennink $J R$, Yewdell JW: Quantitating protein synthesis, degradation, and endogenous antigen processing. Immunity 2003, 18:343-354.

81. Maravillas-Montero $\mathrm{L}$, Santos-Argumedo L: The myosin family: unconventional roles of actin-dependent molecular motors in immune cells. J Leukoc Biol 2011, 91:35-46.

82. Heasman SJ, Ridley AJ: Multiple roles for RhoA during T cell transendothelial migration. Small Gtpases 2010, 1:174-179.

83. Sauer RT, Baker TA: AAA ${ }^{+}$proteases: ATP-fueled machines of protein destruction. Annu Rev Biochem 2011, 80:587-612.

84. Procko E, Gaudet R: Antigen processing and presentation: TAPping into ABC transporters. Curr Opin Immunol 2009, 21:84-91.

85. Authier F, Posner BI, Bergeron JJ: Endosomal proteolysis of internalized proteins. FEBS Lett 1996, 389:55-60.

86. Togashi K, Kataoka T, Nagai K: Characterization of a series of vacuolar type $\mathrm{H}^{+}$-ATPase inhibitors on CTL-mediated cytotoxicity. Immunol Lett 1997 55:139-144.

87. White C, Lee J, Kambe T, Fritsche K, Petris MJ: A role for the ATP7A coppertransporting ATPase in macrophage bactericidal activity. J Biol Chem 2009, 284:33949-33956.

88. Marques-da-Silva C, Chaves MM, Rodrigues JC, Corte-Real S, Coutinho-Silva R, Persechini PM: Differential modulation of ATP-induced P2X7-associated permeabilities to cations and anions of macrophages by infection with Leishmania amazonensis. PLoS One 2011, 6:e25356.

89. Schenk U, Frascoli M, Proietti M, Geffers R, Traggiai E, Buer J, Ricordi C, Westendorf AM, Grassi F: ATP inhibits the generation and function of regulatory $\mathrm{T}$ cells through the activation of purinergic $\mathrm{P} 2 \mathrm{X}$ receptors. $\mathrm{SC}$ Signal 2011, 4:ra12.

90. Straub RH: Evolutionary medicine and chronic inflammatory state-known and new concepts in pathophysiology. J Mol Med (Berl) 2012, 90:523-534

doi:10.1186/ar3885

Cite this article as: Spies CM, et al:: Energy metabolism and rheumatic diseases: from cell to organism. Arthritis Research \& Therapy 2012, 14:216 